\title{
Disinfection of heat-sensitive material by low-temperature steam and formaldehyde
}

\author{
V. G. ALDER, ANNE M. BROWN, AND W. A. GILLESPIE \\ From the Bristol Royal Infirmary and University of Bristol
}

SYNOPSIS Steam under subatmospheric pressure at temperatures below $90^{\circ} \mathrm{C}$. rapidly killed nonsporing organisms after air had been removed by a high-vacuum pump. Most bacterial spores were killed but small proportions of the populations were very resistant. The destruction of spores was not logarithmic.

The addition of formaldehyde vapour to the steam greatly increased its sterilizing power, with deep penetration into fabrics and destruction of spores. Penetration into wide tubes was good, but was poor in narrow tubes. Most fabrics, plastics, and instruments were unharmed. Low-temperature steam with formaldehyde is probably as efficient a sterilizing agent as ethylene oxide.

Steam at $90^{\circ} \mathrm{C}$. has been used to disinfect blankets in this hospital for the past five years (Alder and Gillespie, 1961; Alder and Leitch, 1963). This paper deals with the action of steam at temperatures between $70^{\circ} \mathrm{C}$. and $90^{\circ} \mathrm{C}$. on sporing and nonsporing bacteria, vaccinia virus, and bacteriophage, and with the increased sporicidal action obtained by adding formaldehyde to the steam.

\section{METHODS}

A horizontal, rectangular jacketed autoclave, of $2 \frac{1}{2} \mathrm{cu}$. $\mathrm{ft}$. capacity, was used for most experiments. It was modified by the manufacturers (Drayton-Castle Limited) to operate with steam between $70^{\circ}$ and $100^{\circ} \mathrm{C}$. at pressures down to 20 in. $\mathrm{Hg}$ below atmospheric (Fig. 1). The steam was admitted after preliminary evacuation of air to $29 \cdot 2$ in. $\mathrm{Hg}$ below atmospheric $(20 \mathrm{~mm}$. $\mathrm{Hg}$ absolute pressure). A Drayton 'Dial set 50' controller maintained a constant subatmospheric pressure of steam inside the chamber at a pre-arranged value, by controlling the flow of steam through the inlet valve. When the pressure fell below the preset value the inlet valve opened automatically and closed again when the correct pressure was reached. In this way, temperatures were usually kept within $\pm 2^{\circ} \mathrm{C}$. of the desired values. Steam and condensate escaped intermittently through a chamber discharge valve into an evacuated condenser. The other valves were operated manually and controlled by readings from temperature gauges and barometrically-compensated absolute pressure gauges.

When formaldehyde was required, formalin A.R. $(38 \%$ formaldehyde $\mathrm{w} / \mathrm{v})$ was passed through a steamheated vapouriser into the steam-to-chamber inlet pipe

Received for publication 5 May 1965. before admitting steam. Subsequent evacuation to 29 in. $\mathrm{Hg}$ below atmospheric pressure $(25 \mathrm{~mm}$. absolute) removed the steam and all but a trace of formaldehyde.

Large articles were disinfected in a $55 \mathrm{cu}$. ft. jacketed high-temperature automatic dressings autoclave, which could be operated at high pressure and also, with a separate cycle, at subatmospheric pressure.

PROBLEMS ENCOUNTERED IN OPERATING THE AUTOCLAVES In earlier experiments, condensation was often excessive, but was avoided later by keeping the jacket temperature at $100^{\circ} \mathrm{C}$. with the chamber at $80^{\circ} \mathrm{C}$. The contents were covered with towels or cardboard to shield them from radiant heat. Thermocouple readings showed that the shielding was effective.

Temperature control was disturbed on a few occasions when air leaked into the chamber.

TEST ORGANISMS Suspensions of the following bacteria were made in sterile serum and saline to give viable counts of $10^{5}$ to $10^{6}$ per ml. Overnight cultures of Staphylococcus aureus, Escherichia coli and Streptococcus faecalis, and spore crops of Bacillus subtilis, Bacillus stearothermophilus (N.C.A. 1518) and Clostridium sporogenes (N.C.T.C. 276). Cl. sporogenes spores were prepared as described by Ingram and Handford (1957) and the others as in the Report (1958a).

Volumes, each of $0.1 \mathrm{ml}$,, of all suspensions were freeze dried in small loosely plugged tubes.

Heavy suspensions of all the bacteria in serum were also dried in air on glass chips, aluminium foil, and filter paper. Oxoid spore strips of $B$. stearothermophilus were also used.

Survival of non-sporers after disinfection was investigated by incubating in broth for two days at $37^{\circ} \mathrm{C}$. Spores 


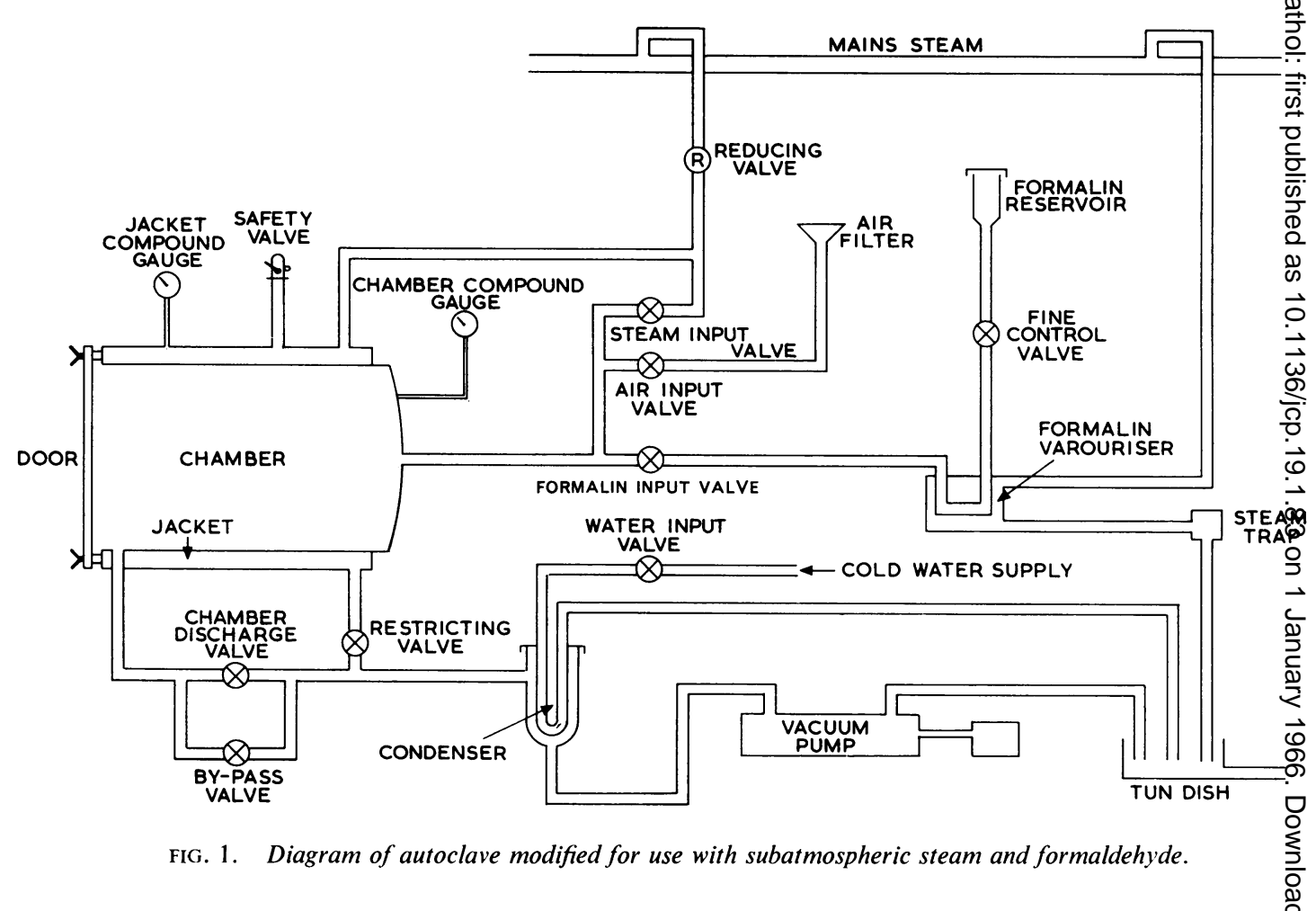

in tubes were re-suspended in distilled water and viable counts performed on the surface of nutrient agar at $37^{\circ} \mathrm{C}$. $\left(56^{\circ} \mathrm{C}\right.$. for B. stearothermophilus). Untreated controls were counted simultaneously. Survival of spores on paper, glass, and foil was determined by three days' incubation in broth at $37^{\circ} \mathrm{C}$. (tryptone dextrose broth at $56^{\circ} \mathrm{C}$. for B. stearothermophilus).

Vaccinia virus was prepared and tested by Dr. S. K. R. Clarke. Volumes, each of $0.2 \mathrm{ml}$, , of a crude chorioallantoic membrane preparation of titre $10^{5} \mathrm{EID}_{50} / \mathrm{ml}$. were freeze dried in $1 \mathrm{ml}$. ampoules kept at $-70^{\circ} \mathrm{C}$. and opened just before disinfection. The contents of each ampoule was then suspended in Earle's saline by a Waring blender, and entirely inoculated into two HeLa cell tubes and incubated for 11 days. Control ampoules contained $10^{6} \mathrm{TCD}_{50}$ of virus. Bacteriophage was freezedried from strong suspensions and tested for survival on propagating staphylococci (Blair and Williams, 1961).

NEUTRALIZATION OF RESIDUAL FORMALDEHYDE The addition of sodium sulphite to neutralize residual formaldehyde (Report, 1958b) delayed the growth of some organisms, especially B. stearothermophilus, on plates. Dilution in broth was employed instead, since experiments showed that the quantities of formaldehyde which might have remained in test objects did not inhibit the sporing bacteria. Germination of $B$. stearothermophilus spores was not impaired by adding $0.025 \%(\mathrm{v} / \mathrm{v})$ formalin A.R. to tryptone dextrose broth. Spores in Oxoid strips germinated after moistening with $0.02 \mathrm{ml}$. of $0.1 \%$ formalin
A.R. before incubation in $15 \mathrm{ml}$. of the broth. B. st.b. spores remained viable after storage for 24 hours at roem temperature in $0.1 \%$ formalin $(\mathrm{v} / \mathrm{v})$.

TESTS OF PENETRATION Penetration of steam $\stackrel{\overline{\mathrm{m}} \mathrm{d}}{\mathrm{d}}$ formaldehyde vapour through fabrics was determined by placing test objects and thermocouples inside a stand pack of 32 cotton towels (size $73 \times 68 \mathrm{~cm}$.), each folded three times. Penetration through wide- and narrow-begre tubes was also investigated. The former was 3.4 metres of polyvinyl tubing $(9.5 \mathrm{~mm}$. bore) containing Oxoid spore strips at intervals of $30 \mathrm{~cm}$., coiled and sealed iäto a bleached Kraft paper bag. The narrow tube wao a $0.5 \mathrm{~mm}$. bore ureteric catheter of braided nylon and yas investigated as suggested by Dr. J. C. Kelsey (persoual communication). The shafts of two 1 in. hypoder needles ( 23 gauge) were inserted into one end of eact tof $f$ two $3 \mathrm{~cm}$. lengths of the catheter tubing and the hijbs fitted to the nozzles of two $2 \mathrm{ml}$. plastic syringe barretss, previously sawn in half transversely. After inserting tost objects, the cut ends of the barrels were smeared with silicone stopcock grease and tightly joined end to enddby rubber pressure tubing and adhesive tape, so as $\frac{\text { to }}{\text { to }}$ constitute a chamber which steam and formaldehyde could enter only through the catheters and needles.

Penetration through two types of paper was studigd. (1) Glassine (16 lb. D.C./480 sheets) when porosity d্নb Bendtsen tester (Hardacker, Bobb, and Wink, 1958) Qas nil, and (2) M.G. Bleached Kraft (21 lb. D.C./480 shegts) when porosity by Bendtsen tester was $250 \mathrm{ml}$./minute 


\section{DISINFECTION BY LOW-TEMPERATURE STEAM}

NON-SPORING ORGANISMS In numerous experiments Staph. aureus, Esch. coli, and Str. faecalis, dried from serum and saline, were always sterilized by steam at $80^{\circ} \mathrm{C}$. for 15 minutes and at $70^{\circ} \mathrm{C}$. for 20 minutes. Vaccinia virus (three tests) and bacteriophage (25 tests) were sterile after exposure to $80^{\circ} \mathrm{C}$. for 30 minutes. Shorter exposure periods were not investigated.

SPORES Steam between $85^{\circ}$ and $90^{\circ} \mathrm{C}$. slowly killed the majority of $B$. subtilis and $B$. stearothermophilus spore populations in freeze-dried preparations, but some always survived after three hours (Figures 2 and 3). The survival curve for $B$. subtilis was not logarithmic, and, as the exposure time lengthened, the additional time needed for a tenfold reduction of the remaining viable spores (the decimal reduction time, or ' $D$ ' value, of Katzyn, Sandholzer, and Strong, 1943) was also increased. The curve for B. stearothermophilus was not determined.

Water at the same temperature as the steam was much less efficient in killing spores (Figures 2 and 3). It was to be expected that steam by releasing latent heat would kill more quickly than hot water, but the size of the difference is difficult to explain. The explanation may lie in easier penetration of spores by steam. Another possibility is inhibition by antirust and anti-scale chemicals in boiler steam, and although this could not be demonstrated the matter needs further investigation.

\section{DISINFECTION OF SPORES BY STEAM WITH FORMALDEHYDE}

Addition of formaldehyde to the steam, in pro- portions varying from $5 \mathrm{ml}$. to $20 \mathrm{ml}$. of formalin per cubic foot of autoclave capacity, greatly increased the rate of destruction of the spores (Figures 2 and 3 and Table I). The improvement was greatest with $B$. stearothermophilus spores, none of which survived exposure to steam and formaldehyde for three hours at $80^{\circ}-85^{\circ} \mathrm{C}$., whereas no tubes treated with steam alone were sterilized (Table I). In steam and formaldehyde at a higher temperature, $85^{\circ}-90^{\circ} \mathrm{C}$., viable counts fell to zero in less than 40 minutes (Figures 2 and 3). All spores, including those dried from serum, were killed in two hours at $80^{\circ} \mathrm{C}$. and in one and a half hours at $90^{\circ} \mathrm{C}$.

\section{PENETRATION THROUGH FABRIC AND PAPER}

STEAM Subatmospheric steam quickly penetrated blankets after removing air (Alder and Gillespie, 1961). In experiments with towel packs at $80^{\circ} \mathrm{C}$., thermocouples showed almost instantaneous heat penetration, and Str. faecalis was sterilized at the centre of the pack in less than 20 minutes.

STEAM WITH FORMALDEHYDE B. stearothermophilus spore strips in glassine envelopes were placed at various depths in standard towel packs. The strips were often sterilized by steam with formaldehyde at lower temperatures, and always above $80^{\circ} \mathrm{C}$. (Table II). The position of the strips in the packs made no material difference to the results and it was evident that the formaldehyde vapour had penetrated deeply (Table III). But the glassine envelopes distinctly hindered penetration, as shown below.

Penetration through glassine and bleached Kraft papers was compared in several experiments in which $B$. stearothermophilus strips in pairs of envelopes, one of each kind, were placed in standard

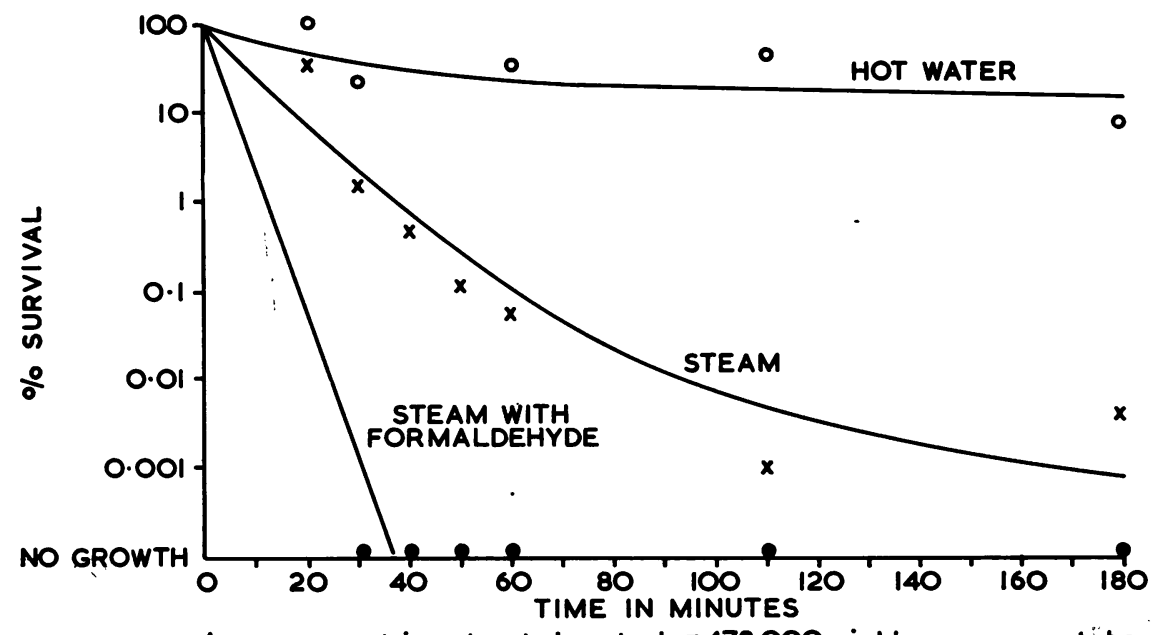

FIG. 2. Survival of B. subtilis spores at $85^{\circ}$ to $90^{\circ} \mathrm{C}$. in hot water, steam, and steam with formaldehyde. 


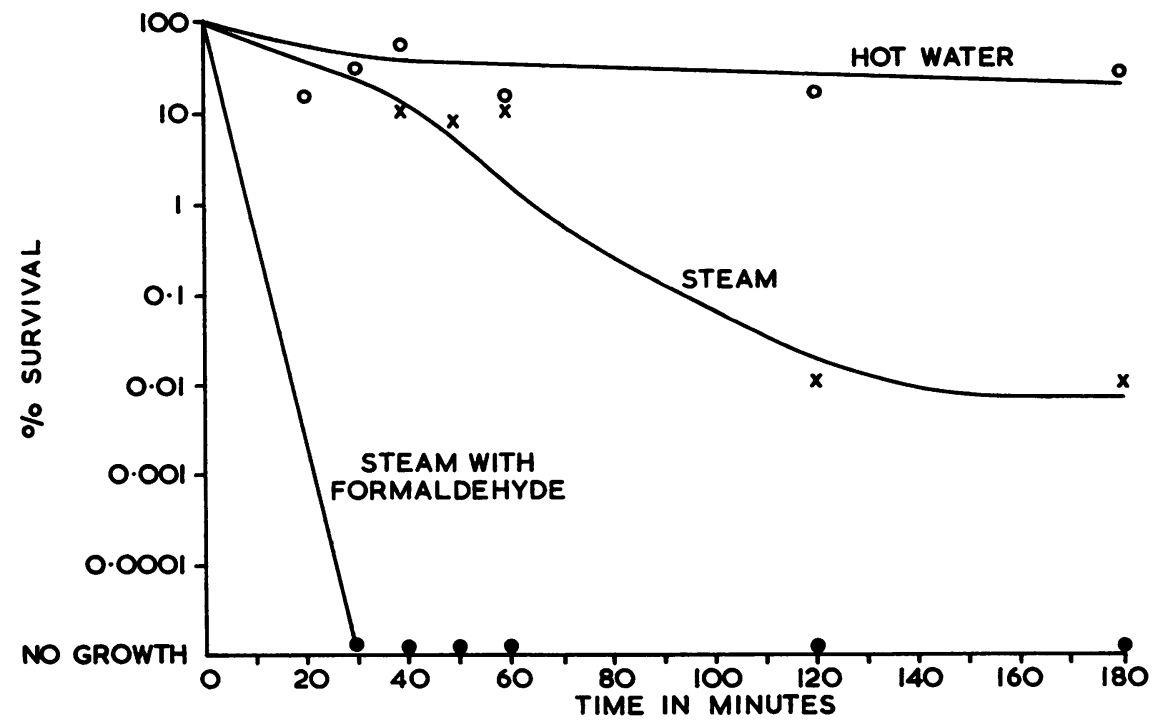

FIG. 3. Survival of B. stearothermophilus spores at 85 ह to $90^{\circ} \mathrm{C}$. in hot water, steam, and \& steam with formaldehyde.

Average count in untreated controls $=900,000$ viable spores per tube

TABLE I

SPORICIDAL ACTION OF STEAM AND STEAM-WITH-FORMALDEHYDE AT $80^{\circ} \mathrm{c}$. TO $85^{\circ} \mathrm{C}$.

Steam

Steam with formaldehyde

Steam with formaldehyde Steam

B. subtilis in tubes

$B$. subtilis in tubes

B. subtilis in tubes

Cl. sporogenes in tubes

$\mathrm{Cl}$. sporogenes in tubes
Steam with formaldehyde

Steam with formaldehyde

Steam

Steam with formaldehyde

\begin{tabular}{l} 
Exposure \\
\hline 3 hours \\
3 hours \\
1 hour \\
3 hours \\
3 hours \\
1 hour \\
1 hour \\
1 hour
\end{tabular}

\section{TABLE II}

INFLUENCE OF DURATION OF EXPOSURES, TEMPERATURE, AND COMPOSITION OF STEAM/FORMALDEHYDE MIXTURE ON STERILIZATION OF B. STEAROTHERMOPHILUS SPORE STRIPS IN TOWEL PACKS AND POLYTHENE TUBES

Position of Strips

\begin{tabular}{ll} 
& $\left({ }^{\circ} \mathrm{C}.\right)$ \\
& \\
\hline In glassine paper envelopes inside & $60-70$ \\
towel packs & $70-78$ \\
& $70-78$ \\
& $70-78$ \\
& $70-78$ \\
& $74-77$ \\
& $80-85$ \\
Bare strips at $30 \mathrm{~cm}$. intervals in & $80-85$ \\
Polythene tube & $80-89$ \\
Autoclave atmosphere & $70-71$ \\
& $70-78$ \\
& $70-78$ \\
& $70-78$
\end{tabular}

Volume of Formalin Injected per Cubic Foot of Autoclave Capacity (ml.)

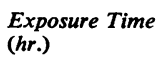

20
20
20
20
20
6
20
20
6
20
20
20
20

'One failure in towel wetted by condensation.

\begin{tabular}{|c|c|}
\hline 52 & 0 \\
\hline 40 & 40 \\
\hline 114 & 49 \\
\hline 9 & 6 \\
\hline 9 & 9 \\
\hline 8 & 7 \\
\hline 7 & 4 \\
\hline 7 & 7 \\
\hline
\end{tabular}


TABLE III

STERILIZATION OF B. STEAROTHERMOPHILUS SPORE STRIPS PLACED AT DIFFERENT DEPTHS IN STANDARD TOWEL PACKS (SUMMARIZED FROM TABLE II)

Position of Spore Strips

\begin{tabular}{|c|c|c|c|c|c|c|c|c|c|c|c|c|c|c|}
\hline $\begin{array}{l}\text { No. of towels from top of pack } \\
\text { No. of strips exposed } \\
\text { No. of strips sterilized } \\
\text { No. of strips sterilized in groups of } \\
\text { eight towels }\end{array}$ & $\begin{array}{r}2 \\
15 \\
9 \\
21\end{array}$ & $\begin{array}{r}4 \\
16 \\
5\end{array}$ & $\begin{array}{r}6 \\
15 \\
7\end{array}$ & $\begin{array}{r}8 \\
19 \\
7\end{array}$ & $\begin{array}{r}10 \\
16 \\
9\end{array}$ & $\begin{array}{r}12 \\
16 \\
3\end{array}$ & $\begin{array}{r}14 \\
16 \\
9\end{array}$ & $\begin{array}{l}16 \\
21 \\
10\end{array}$ & $\begin{array}{r}18 \\
12 \\
3\end{array}$ & $\begin{array}{r}20 \\
16 \\
8\end{array}$ & $\begin{array}{r}22 \\
16 \\
4\end{array}$ & $\begin{array}{r}24 \\
18 \\
8\end{array}$ & $\begin{array}{r}26 \\
18 \\
8\end{array}$ & $\begin{array}{l}28 \\
16 \\
10\end{array}$ \\
\hline
\end{tabular}

towel packs and exposed to steam with formaldehyde ( $5 \mathrm{ml}$. formalin per cu. $\mathrm{ft}$.) at temperatures between $71^{\circ}$ and $84^{\circ} \mathrm{C}$. Below $80^{\circ} \mathrm{C}$. spores survived for two hours in 27 of 30 glassine envelopes compared with 15 of 30 in bleached Kraft. At $81^{\circ}$ to $84^{\circ} \mathrm{C}$. for one hour, the survival rate in glassine was $14 / 30$, compared with $0 / 30$ in bleached kraft. The same mixture freely entered cardboard boxes. Survival rates of spore strips in bleached kraft envelopes in a Bri-pac carton treated at $79^{\circ}$ to $84^{\circ} \mathrm{C}$. were $1 / 24$ after one and a half hours and $0 / 20$ after two hours.

Glassine envelopes, being transparent, allow recognition of enclosed instruments. This advantage can be retained, without hindering penetration, in an envelope made of both papers such as the WindowBag (E. S. \& A. Robinson).

\section{PENETRATION INTO TUBES}

Steam with formaldehyde freely entered and killed $B$. stearothermophilus in the wide tube (Table II), but steam and steam with formaldehyde penetrated badly into the narrow ureteric catheter (Table IV).
Several non-sporing bacteria survived for an hour in steam between $68^{\circ}$ and $80^{\circ} \mathrm{C}$. and one survived in steam with formaldehyde. Spore strips often contained survivors after treatment in steam with formaldehyde, even after five hours on one occasion.

\section{DAMAGE TO INSTRUMENTS AND FABRICS}

Alder and Gillespie (1961) showed that 50 exposures to steam at $90^{\circ} \mathrm{C}$. did not damage woollen blankets, and subsequent experience has confirmed this. The blankets became markedly creased when bundled unfolded into sacks and disinfected without unpacking. The creases disappeared during use, but if desired can be avoided altogether, though at some cost in time, by folding and packing blankets in shaped bags (Alder and Leitch, 1963). Cotton blankets were not creased.

Steam at $80^{\circ} \mathrm{C}$. severely damaged leather and slightly blistered some painted metal surfaces, though others were unaffected. Polystyrene softens at $70^{\circ} \mathrm{C}$. and articles made from this material are distorted in low temperature steam above this temperature.

TABLE IV

ACTION OF STEAM AND STEAM WITH FORMALDEHYDE ON BACTERIA IN URETERIC CATHETERS

\begin{tabular}{|c|c|c|c|c|c|c|c|}
\hline \multirow{4}{*}{$\begin{array}{l}\text { Duration of } \\
\text { Exposure } \\
\text { (min.) }\end{array}$} & \multirow[t]{4}{*}{$\begin{array}{l}\text { Temperature } \\
\text { Range }\left({ }^{\circ} \mathrm{C} .\right)\end{array}$} & \multicolumn{4}{|c|}{ Proportion of Cultures Not Sterilized" } & \multirow{2}{*}{\multicolumn{2}{|c|}{ B. stearothermophilus Spore }} \\
\hline & & Non-sporer & & & \multirow{3}{*}{ Controls 2} & & \\
\hline & & \multicolumn{3}{|l|}{ Catheters } & & \multirow[t]{2}{*}{ Catheters } & \multirow[t]{2}{*}{ Controls $^{2}$} \\
\hline & & S. aureus & E. coli & Str. faecalis & & & \\
\hline $\begin{array}{c}\text { Steam } \\
10 \\
30 \\
60 \\
120\end{array}$ & $\begin{array}{l}68-75 \\
67-80 \\
79-80 \\
77-80\end{array}$ & $\begin{array}{l}1 / 1 \\
0 / 16 \\
1 / 20 \\
0 / 12\end{array}$ & $\begin{array}{l}1 / 1 \\
2 / 16 \\
1 / 20 \\
0 / 12\end{array}$ & $\begin{array}{l}1 / 1 \\
3 / 16 \\
3 / 20 \\
0 / 12\end{array}$ & $\begin{array}{l}\text { Equal numbers } \\
\text { of controls all } \\
\text { sterile }\end{array}$ & $\begin{array}{l}- \\
-\end{array}$ & $\bar{z}$ \\
\hline $\begin{array}{l}\text { Steam with } f \\
10 \\
30 \\
60 \\
120 \\
180 \\
240 \\
300 \\
300\end{array}$ & $\begin{array}{l}\text { rmaldehyde } \\
75-76 \\
76-77 \\
75-79 \\
80 \\
66-69 \\
67-73 \\
67-73 \\
81-83\end{array}$ & $\begin{array}{l}1 / 1 \\
0 / 7 \\
1 / 12 \\
0 / 4 \\
\overline{0 / 1} \\
\overline{0 / 10}\end{array}$ & $\begin{array}{l}1 / 1 \\
0 / 6 \\
0 / 12 \\
0 / 4 \\
\frac{0}{0 / 1} \\
\overline{0 / 10}\end{array}$ & $\begin{array}{l}0 / 1 \\
0 / 7 \\
0 / 12 \\
0 / 4 \\
\frac{0}{0 / 1} \\
\frac{\pi}{0 / 18}\end{array}$ & $\begin{array}{l}\text { Equal numbers } \\
\text { of controls all } \\
\text { sterile }\end{array}$ & $\begin{array}{l}1 / 1 \\
3 / 7 \\
5 / 10 \\
0 / 4 \\
1 / 9 \\
2 / 4 \\
8 / 18 \\
1 / 8\end{array}$ & $\begin{array}{l}1 / 1 \\
3 / 5 \\
0 / 10 \\
0 / 4 \\
0 / 16 \\
0 / 10 \\
1 / 30 \\
0 / 5\end{array}$ \\
\hline
\end{tabular}

'Each fraction shows $\frac{\text { Number cultures not sterilized }}{\text { Number exposed }}$

2Control tests were placed in Petri dishes in the autoclave. $-=$ not tested. 
The following articles were not damaged by steam alone and with formaldehyde. (Those marked * were treated once and others several times.)

At $80^{\circ} \mathrm{C}$.: Nylon fur; *nylon fabric; *terylene fabric; *acrilan fabric; *rayon fabric; polyurethane; teflon tubing; epoxy resins; silicone rubber; perspex (moulded and flat); cystoscopes and other endoscopic instruments with electric light bulbs; electric leads and switches and bakelite plugs; *an electric motor; *a capacitor; ball point pens without ink reservoirs (the treatment causes the ink to ooze); *a worsted suit; *clothing for disinfestation; *a baby's carry-cot; gum elastic catheters; latex rubber catheters; cuffed endotracheal tubes; a Rubens valve for anaesthetic apparatus; a cyclator for anaesthetic apparatus; a Radcliffe humidifier; a Cape respirator with pressure gauge removed; *a packet of tea (in steam only).

At $90^{\circ} \mathrm{C}$ : : Rubber anaesthetic face masks and tubing; tracheostomy tubes; Portex translucent polyvinyl tubing for peritoneal dialysis and perfusions; books; magazines; documents with ordinary ink writing; surgeons' boots and nurses' theatre shoes.

\section{REMOVAL OF FORMALDEHYDE AFTER DISINFECTION}

Usually no smell of formaldehyde was detected in disinfected articles though sometimes there was a faint smell on first opening the autoclave. Phenylhydrazine tests revealed traces of formaldehyde in gum elastic catheters and rubber latex tubes. The amount was too small to determine quantitatively, but was less than $0.01 \%$ in $25 \mathrm{~g}$. of gum elastic catheter material (H. E. Groves, personal communication).

Residual formaldehyde might have been removed more thoroughly by flushing with steam and evacuating the chamber again but this procedure was not investigated.

\section{DISCUSSION}

The growing use of complicated surgical apparatus and plastic equipment, some of which is damaged at high temperatures, has increased the need for alternative methods of sterilization. These, though inevitably less efficient than high temperature methods, must be acceptably safe and reliable in the circumstances for which they are intended. Ethylene oxide provides one such method but it is not an easy sterilizing technique to use. Kelsey (1963) stated that because of its many variables ethylene oxide is probably the one sterilizing agent that can be effectively controlled only by bacteriological means. The results presented here suggest that steam at subatmospheric pressures is another suitable disi蕁 fecting agent, and that when mixed with formaldehyde vapour and used above $70^{\circ} \mathrm{C}$, it is comparabete in potency with ethylene oxide. However, the value and limitations of the method cannot be assessed until it has been more widely used. The apparatis can be controlled by pressure (as in the prese series of experiments) or by the temperature at the bottom of the chamber. Leakage of air must be avoided since it would hinder penetration and als $\overrightarrow{\theta_{0}}$ by disturbing temperature control, might damage heat-sensitive instruments. This danger could ges altogether avoided by arranging for the steam inleft valve to close automatically if the temperature in the upper part of the chamber rises to $5^{\circ}$ above the operating temperature.

Subatmospheric steam at $80^{\circ}$ to $85^{\circ} \mathrm{C}$. rapide\% penetrated porous fabrics from which air had been removed by an efficient pump, and destroyed vaccinia virus and non-sporing bacteria. The steam wht disinfect articles such as bedding and some end $\vec{E}$ scopic instruments, where contamination by sporess is unimportant. Although subatmospheric steam at $90^{\circ} \mathrm{C}$. did not sterilize spore suspensions, it destroyes the majority of spores in the populations tested and was more efficient than water at the same temperg. ture. The survival graphs of spores in heate suspensions were in accordance with the results 8 ff Reynolds and Lichtenstein (1952) and Vas and Proszt (1957). Most spores were quickly killed bQgt a few remained viable after prolonged heating. Sueh variability within one population has been attributed to differences in the physiological development of spores in suspensions prepared by ordinary culturiani methods (Halvorson, 1957). Powell (1957) als̈ demonstrated heterogeneity in spore populations. Hence different preparations of the same strain might differ in heat resistance unless survival curvees were plotted with suspensions of uniform physiological state, perhaps prepared by synchronous culture. It is the existence of the few very resistagt members of spore populations which makes it necessary to employ high temperatures in heg.t sterilizers. The chance that some spores will survive at lower temperature partly depends on the size $8 \mathrm{f}$ the population. Hence even boiling in water, $\widetilde{J}_{a}$ manifestly imperfect method of sterilization, has th the past been reliable for lightly contaminated objegrs such as well-washed instruments.

The addition of formaldehyde to subatmospheric steam made it much more lethal to spores. stearothermophilus was killed almost as quickly ass $B$. subtilis and $\mathrm{Cl}$. sporogenes. In suitable conditiog of temperature and humidity the main limitation 80 the use of formaldehyde vapour as a sterilant is $\overrightarrow{g t s}$ poor penetrative power (Report, 1958b). Nordgre 
(1939) showed that if the temperature was raised and the chamber evacuated before admitting formaldehyde penetration was improved and spores coated with blood or sputum could be sterilized in two hours. The present work showed that formaldehyde in steam penetrated well into non-woollen fabrics and wide tubes after air had been removed by a highvacuum pump of the type now fitted to dressing sterilizers. Early experiments demonstrated some penetration into woollen fabric, but this was not investigated further. Penetration into narrow tubes was poor, perhaps because traces of air remaining after evacuation were not displaced by the steam. This fault is shared by ethylene oxide (J. C. Kelsey, personal communication).

Cardboard for use in a low-temperature steam disinfector should first have been sterilized at high temperatures to destroy spores (Report, 1958a).

Some margin of safety should be allowed when disinfecting instruments and equipment, though they would rarely be as heavily contaminated as in the experiments reported here. The following exposures, probably unnecessarily long, have been used for routine disinfection:-Steam, 20 minutes at $80^{\circ} \mathrm{C}$. or 30 minutes at $70^{\circ} \mathrm{C}$.; steam with formaldehyde ( $5 \mathrm{ml}$. formalin A.R. per cu. $\mathrm{ft}$. of autoclave space), two hours at $80^{\circ} \mathrm{C}$. for deep penetration through fabric and two hours at $70^{\circ} \mathrm{C}$. for shallow penetration, e.g., through bleached Kraft paper, and surface sterilization.

We gratefully acknowledge the financial assistance of the Nuffield Provincial Hospitals Trust, and the advice and help of Dr. J. C. Kelsey, Dr. S. K. R. Clarke, Dr. J. A. Clement, Mr. K. M. Henfrey (Drayton Castle Co. Ltd.), Mr. M. I. Lees, Miss G. Patient, Dr. R. Winter (E.S. \& A. Robinson Ltd.), and Mr. T. W. G. Rowe (Edwards High Vacuum International Ltd.). We also thank Mr. H. Eardley Groves (R. A. Cripps \& Sons Ltd., Brighton) for estimating formaldehyde.

\section{REFERENCES}

Alder, V. G., and Gillespie, W. A. (1961). J. clin. Path., 14, 515. and Leitch, C. W. (1963). Hospital (Lond.), 59, 662.

Blair, J. E., and Williams, R. E. O. (1961). Bull. Wld Hlth Org., 24, 771. Halvorson, H. O. (1957). J. appl. Bact., 20, 305.

Hardacker, K. W., Bobb, F. C., and Wink, W. A. (1958). J. Tech. Ass. Pulp Paper Industr., 41, 191.

Ingram, M., and Handford, P. M. (1957). J. appl. Bact., 20, 442.

Katzyn, L. I., Sandholzer, L. A., and Strong, M. E. (1943). J. Bact. 45, 265.

Kelsey, J. C. (1963). J. clin. Path., 16, 542.

Nordgren, G. (1939). Acta path. microbiol. scand., suppl. 40.

Powell, E. O. (1957). J. appl. Bact., 20, 342.

Report (1958a). Present Sterilizing Practice in Six Hospitals. Nuffield Provincial Hospitals Trust, London.

Report (1958b). J. Hyg. (Lond.), 56, 488.

Reynolds, H., and Lichtenstein, H. (1952). Bact. Rev., 16, 126.

Vas, K., and Proszt, F. (1957). J. appl. Bact., 20, 431. 